\title{
EVALUASI PELAKSANAAN MODEL PEMBELAJARAN TEACHING FACTORY DI SMKN 1 CIBADAK
}

\section{Evaluation Learning Model of Teaching Factory Implementation at SMKN 1 Cibadak}

\author{
Zahra Pitaloka Prasloranti*, Masriam Bukit, Shinta Maharani \\ Pendidikan Teknologi Agroindustri, \\ Fakultas Pendidikan Teknologi dan Kejuruan, Universitas Pendidikan Indonesia \\ *zahrapitaloka42@upi.edu
}

\begin{abstract}
ABSTRAK
Model pembelajaran teaching factory (TEFA) adalah model pembelajaran di SMK berbasis produksi atau jasa yang mengacu pada standar, prosedur, dan suasana seperti di industri. Salah satu sekolah yang mengadopsi model pembelajaran TEFA adalah SMK Negeri 1 Cibadak. Dalam keberlangsungan suatu program, perlu ada proses yang digunakan untuk menilai tingkat keterlaksanaan program yang disebut evaluasi. Penelitian ini menggunakan model evaluasi CIPP yang berorientasi kepada empat komponen yaitu context, input, process, dan product. Tujuan penelitian ini adalah untuk mengetahui sejauh mana implementasi model pembelajaran TEFA ditinjau dengan komponen CIPP. Pengumpulan data dalam penelitian ini dilakukan melalui kuesioner, wawancara, observasi, dan dokumentasi. Hasil penelitian diketahui bahwa pelaksanaan model pembelajaran TEFA komponen context termasuk kedalam kategori sangat sesuai terhadap relevansi pelaksanaan dengan tujuan program, visi, dan misi sekolah. Komponen input termasuk kedalam kategori sesuai dengan manajemen sekolah, saranaprasarana, dan sumber daya manusia. Komponen process termasuk kedalam kategori sangat sesuai dengan pola pembelajaran dan marketing. Komponen product termasuk kedalam kategori sangat sesuai dengan produk dan kompetensi siswa. Seluruh komponen CIPP model pembelajaran TEFA telah terlaksana dengan baik tetapi memerlukan peningkatan dalam pengembangan teknologi, penyelarasan kurikulum, pengelolaan sumber daya, dan pemasaran produk.
\end{abstract}

Kata kunci: CIPP, evaluasi, teaching factory (TEFA)

\begin{abstract}
The teaching factory learning model (TEFA) is a production or service-based learning model in the vocational school that refers to the standards, procedures, and industry-like atmosphere. One of the schools that adopts the TEFA learning model is SMKN 1 Cibadak. To continuity of a program, it needs to assess the learning process, which is called evaluation. This study uses the CIPP evaluation model, which is oriented towards four components: context, input, process, and product. This study aimed to determine the implementation of the TEFA learning model in terms of the CIPP aspect. Data collection in this study was carried out through questionnaires, interviews, observation, and documentation. The results showed that TEFA context component was in line with the school's objectives, visions, and missions. The input components are included in the more appropriate category for school management, infrastructure, and human resources. The process component is included in the most appropriate category for learning methods and marketing. The product components are also most appropriate for the product and student competencies. All components of the CIPP TEFA learning model have been implemented well but require improvements in technology development, curriculum alignment, resources management, and product marketing.
\end{abstract}

Keywords: CIPP, evaluation, teaching factory (TEFA) 


\section{PENDAHULUAN}

Upaya pemerintah untuk meningkatkan kualitas SDM dilaksanakan melalui berbagai program pendidikan, salah satu program prioritas untuk merealisasikan visi terbentuknya insan dan ekosistem yang berkarakter dengan program pengembangan model pembelajaran teaching factory atau TEFA. Berdasarkan PP Nomor 41 Tahun 2015 bahwa model pembelajaran TEFA SMK disebut sebagai pabrik dalam sekolah berupa sarana produksi berdasarkan prosedur dan standar bekerja sesungguhnya untuk menghasilkan produk sesuai dengan industri dan tidak berorientasi dalam mencari keuntungan.

Kondisi ideal dari implementasi model pembelajaran TEFA di SMK menurut Direktorat PSMK (2017) meliputi aspek pembelajaran, sumber daya manusia, fasilitas, kegiatan praktik, jaringan kerja sama, produk/jasa, transparansi, serta aspek legal. Penjabaran kondisi ideal tersebut meliputi berbagai aspek seperti pada aspek pembelajaran bahwa sistem penilaian telah berbasis model pembelajaran TEFA dan sistem pembelajarannya menggunakan jadwal blok dan kontinyu. Aspek sumber daya manusia meliputi guru, tenaga non-pendidik, dan tenaga penunjang lain dalam pelaksanaan sosialisasi, penyusunan rencana pengembangan kualitas SDM, pelaksanaan magang industri, penyusunan penerapan hasil kerja SMK, pemetaan mengajar guru sesuai model pembelajajran, dan melakukan monitoring serta evaluasi (monev) pengajaran guru (Direktorat PSMK, 2017).

Aspek fasilitas sekolah perlu memenuhi rasio 1:1 antara siswa dengan alat, perawatan peralatan menerapkan sistem maintenance, repair, and calibration (MRC), alat bantu proses produksi lengkap, dan peralatan dilakukan pengembangan dengan penambahan dan pergantian alat. Aspek kegiatan praktik berupa penerapan budaya industri dengan adanya standar kualitas produk, target waktu, efisiensi proses, rotasi kerja, produk kerja yang jelas, hasil praktik menjadi sumber pendapatan, dan fungsi serta tanggung jawab yang jelas. Aspek jaringan kerja sama berupa hubungan kerja sama antara sekolah dengan dunia industri agar dapat berlangsung secara berkesinambungan. Aspek produk dalam penentuan produk ditentukan dengan sasaran penggunaan, kualifikasi pengguna, volume produk, penentuan waktu, serta permintaan secara kontinyu atau insidential. Aspek transparansi berupa pencatatan transaksi keuangan sesuai dengan standar prosedur akuntansi meliputi kegiatan pencatatan, seperti pembukuan transaksi keuangan, jurnal khusus, buku besar, hingga laporan akhir (Direktorat PSMK, 2017).

Salah satu sekolah yang mengadopsi model pembelajaran TEFA adalah SMK Negeri 1 Cibadak. Penerapan model pembelajaran TEFA bertujuan untuk mengembangkan lifeskill siswa, dilaksanakan dalam blok waktu, memberikan pengalaman secara langsung mengenai kehidupan sosial dan industri di sekolah, serta mencapai kompetensi belajar dalam mata pelajaran produksi (Martawijaya, 2015). Program studi teknologi hasil pertanian SMKN 1 Cibadak memiliki beberapa unit TEFA, seperti unit produksi roti, yoghurt, bakpia, sari buah lemon (SBL), keripik, dan herbal. Berdasarkan hasil wawancara dan observasi pra-penelitian, kegiatan produksi model pembelajaran TEFA di SMKN 1 Cibadak dalam pelaksanaannya masih mengikuti instruksi dari supervisor produksi. Jumlah guru dan siswa belum sesuai dengan standar rasio pengajar dengan siswa yakni 1 orang guru memegang 30-35 orang siswa untuk pekerjaan manual, sementara dalam standar seorang guru idealnya memegang 12-20 orang siswa. Belum terdapat kartu maintenance, repair, and calibration (MRC) alat untuk pengelolaan mesin produksi, belum tersedianya SOP, alur kerja, dan struktur organisasi di unit produksi.

Pengembangan TEFA di SMKN 1 Cibadak dilaksanakan semenjak tahun 2014, salah satunya pada TEFA unit serealia yang memiliki produk bakpia ubi ungu. Unit produksi ini termasuk baru, bersamaan dengan unit produksi sari buah lemon. Namun produk sari buah lemon telah memiliki hubungan kerja sama dengan industri yang langsung membawahi proses produksi, sementara unit produksi bakpia belum memiliki kerja sama industri yang membawahi secara langsung. Berdasarkan observasi pra-penelitian, unit produksi bakpia ini dinilai memiliki proses yang lebih sederhana dibandingkan produk TEFA lainnya sehingga sekolah menganggap belum saatnya melaksanakan evaluasi secara menyeluruh. Untuk mengetahui hasil akhir dari program, perlu dilaksanakan evaluasi program dalam rangkan menentukan rekomendasi kebijakan yang lalu sehingga tujuan akhirnya menentukan kebijakan selanjutnya (Suharsimi dkk, 2008).

Terdapat beberapa model evaluasi pada bidang pendidikan, seperti model kesenjangan, model evaluasi formatif, model evaluasi sumatif, model CIPP, model pengukuran, model persesuaian, model 
evaluasi sistem pendidikan, dan lainnya (Suharsimi dkk, 2008). Model evaluasi program yang konsisten dengan fokus perbaikannya adalah model CIPP dengan memprioritaskan pengarahan perencanaan dan pelaksanaan dalam upaya pembangunan (Stufflebeam dkk, 2008). Keberhasilan model pembelajaran TEFA di sekolah dapat terlaksana dengan baik apabila komponen-komponen pelaksanaan model pembelajaran TEFA memiliki nilai ketercapaian yang tinggi. Komponen-komponen tersebut meliputi context, input, process, dan product dalam mengevaluasi program secara keseluruhan. Dengan adanya evaluasi, institusi dapat menentukan komponen mana yang nilai ketercapaiannya tinggi atau rendah serta dapat mengambil keputusan untuk mempertahankan yang telah terlaksana maupun memperbaiki yang belum terpenuhi.

Menurut penelitian Indahsari (2017) bahwa evaluasi pelaksanaan model pembelajaran TEFA di SMK berupa ukuran efektivitas dan rekomendasi pelaksanaan model TEFA untuk perbaikan kedepannya, dengan harapan evaluasi juga dapat menghasilkan saran perbaikan yang dibutuhkan. Berdasarkan pernyataan tersebut, tujuan dari penelitian ini adalah untuk mengetahui sejauh mana implementasi pembelajaran TEFA unit produksi bakpia di SMKN 1 Cibadak menggunakan model evaluasi CIPP yang ditinjau dari masing-masing komponen context, input, process, dan product.

\section{METODE}

Penelitian ini dilaksanakan berdasarkan evaluasi model pembelajaran TEFA dengan metode penelitian deskriptif kuantitatif model evaluasi CIPP dari Daniel Stufflebeam (Jenkins, 1976). Komponen context terdiri atas latar belakang program, visi, misi, dan tujuan yang dicapai. Komponen input terdiri atas sarana-prasarana dan sumber daya manusia. Komponen process berhubungan dengan implementasi pelaksanaan pembelajaran, seperti pola pembelajaran dan kegiatan marketing. Komponen product terdiri atas produk yang dihasilkan dan kompetensi siswa. Partisipan yang dipilih terlibat dalam pelaksanaan pembelajaran, yaitu guru ahli bidang pengolahan, supervisor produksi, siswa kelas XII jurusan TPHP, kepala sekolah, dan konsumen. Sampel berupa satu kelompok produksi berjumlah 5 orang siswa, satu orang guru ahli bidang pengolahan, satu orang supervisor produksi, dan konsumen sebanyak 3 orang. Analisis data angket yang digunakan dengan menggunakan skala Likert. Responden kuesioner terbagi berdasarkan komponen evaluasi yang digunakan dapat dilihat pada Tabel 1.

Tabel 1. Tabel Responden Angket

\begin{tabular}{|c|c|c|}
\hline No. & Komponen & Responden \\
\hline & Input & Penanggung jawab TEFA \\
\hline & & Guru ahli bidang pengolahan \\
\hline & & Supervisor produksi \\
\hline \multirow[t]{4}{*}{2.} & Process & Penanggung jawab TEFA \\
\hline & & Guru ahli bidang pengolahan \\
\hline & & Supervisor produksi \\
\hline & & $\begin{array}{l}\text { Siswa yang melaksanakan kegiatan TEFA ( } 1 \\
\text { kelompok berjumlah } 5 \text { orang) }\end{array}$ \\
\hline & Product & Penanggung jawab TEFA \\
\hline & & Guru ahli bidang pengolahan \\
\hline & & Supervisor produksi \\
\hline & & $\begin{array}{l}\text { Siswa yang melaksanakan kegiatan TEFA ( } 1 \\
\text { kelompok berjumlah } 5 \text { orang) }\end{array}$ \\
\hline & & Konsumen produk (berjumlah 3 orang) \\
\hline
\end{tabular}

Sumber: Modifikasi terhadap responden dari Indahsari (2017)

Kegiatan wawancara menggunakan panduan yang dibuat dalam bentuk pedoman wawancara yang dapat dilihat di bagian Lampiran. Responden wawancara terbagi berdasarkan komponen evaluasi yang digunakan dapat dilihat pada Tabel 2.

Tabel 2. Tabel Responden Wawancara

\begin{tabular}{cll}
\hline No. & \multicolumn{1}{c}{ Komponen } & \multicolumn{1}{c}{ Responden } \\
\hline 1. & Context & Kepala sekolah \\
\cline { 3 - 3 } 2. & Input & Penanggung jawab TEFA \\
\hline 3. & Process & $\begin{array}{l}\text { Suru ahli bidang pengolahan } \\
\text { Survisor produksi }\end{array}$ \\
\hline & & $\begin{array}{l}\text { Siswa yang melaksanakan kegiatan TEFA (1 } \\
\text { kelompok berjumlah } 5 \text { orang) }\end{array}$ \\
\hline
\end{tabular}




\begin{tabular}{ll} 
4. Product & $\begin{array}{l}\text { Siswa yang melaksanakan kegiatan TEFA (1 } \\
\text { kelompok berjumlah } 5 \text { orang) }\end{array}$ \\
& Konsumen (berjumlah 3 orang) \\
\hline
\end{tabular}

Dokumentasi dilakukan dengan pengumpulan data-data seperti buku, dokumen, video, dan catatan lain yang berhubungan dengan objek yang diteliti. Pengumpulan data dilakukan dalam bentuk pengumpulan dokumen, daftar dokumen yang dikumpulkan dapat dilihat pada Tabel 3.

Tabel 3. Daftar Dokumen

\begin{tabular}{cl}
\hline No. & \multicolumn{1}{c}{ Dokumen yang Dibutuhkan } \\
\hline 1. & Laporan pencatatan transaksi keuangan teaching factory \\
\hline 2. & SOP kinerja \\
\hline 3. & Alur kerja model pembelajaran teaching factory \\
\hline 4. & Inventarisasi peralatan produksi \\
\hline 5. & Standar pemakaian alat \\
\hline 6. & Dokumen rambu-rambu K3 \\
\hline 7. & Dokumen layout ruang produksi \\
\hline 8. & RPP dan LKS \\
\hline 9. & Dokumen rencana marketing dan promosi \\
\hline 10. & Data nilai siswa \\
\hline
\end{tabular}

Sumber: Modifikasi terhadap penambahan daftar dokumen dari Indahsari (2017)

Data penelitian yang diperoleh diolah dan dianalisa secara deskriptif. Kategori data hasil penelitian dibagi menjadi 4 (empat) kategori yang dapat dilihat pada Tabel 4.

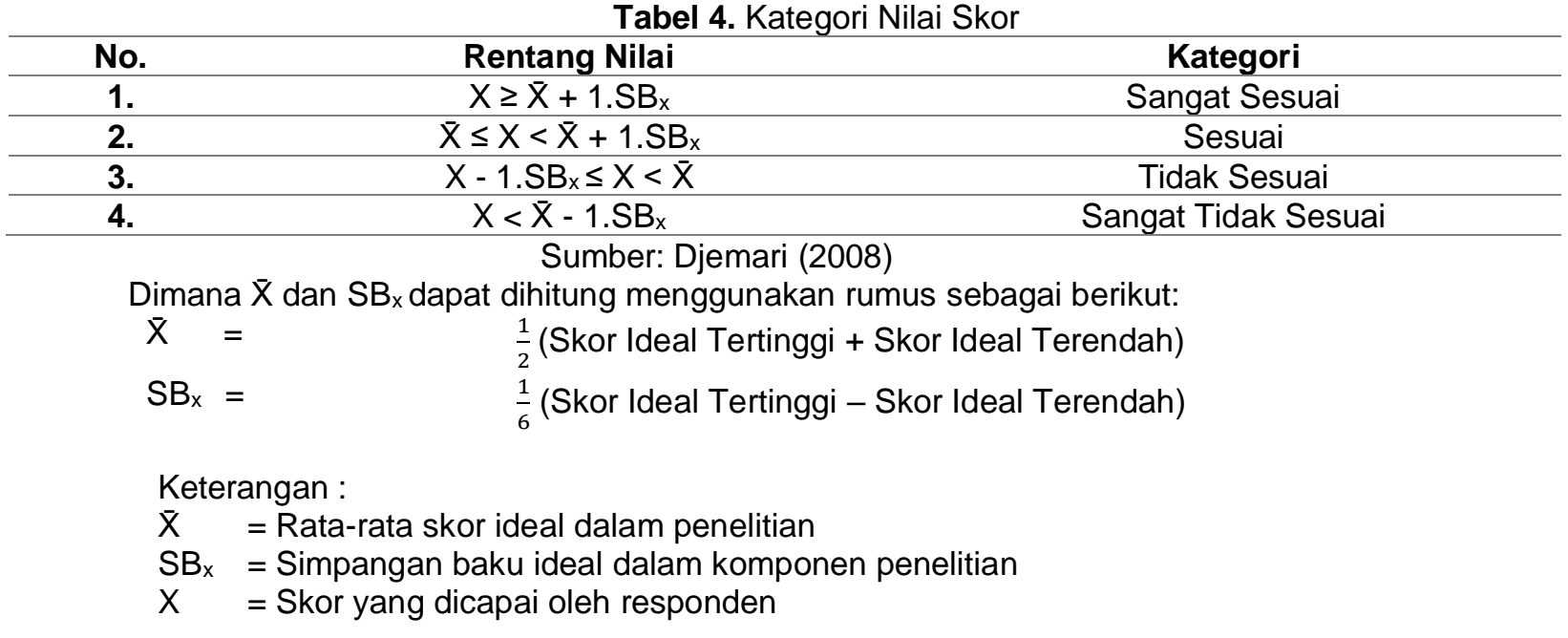

Pengelompokan kategori untuk masing-masing komponen evaluasi model pembelajaran TEFA sebagai berikut:

1. Evaluasi Input

a. Angket Penanggung Jawab TEFA, Guru Ahli Bidang Pengolahan, dan Supervisor Produksi

Angket terdiri atas 38 pernyataan dengan 4 pilihan jawaban menggunakan skala Likert rentang nilai 1 hingga 4. Skor ideal terendah bernilai 38 dan skor ideal tertinggi bernilai 152.

Tabel 5. Kategori Data Angket Komponen Input Responden Guru

\begin{tabular}{rcc}
\hline No. & Rentang Nilai & Kategori \\
\hline 1. & $X \geq 114$ & Sangat Sesuai \\
\hline 2. & $95 \leq X<114$ & Sesuai \\
\hline 3. & $76 \leq X<95$ & Tidak Sesuai \\
\hline 4. & $X<76$ & Sangat Tidak Sesuai \\
\hline \multicolumn{2}{c}{ Sumber: Djemari (2008) } \\
\hline
\end{tabular}

\section{b. Angket Siswa}

Angket terdiri atas 25 pernyataan dengan 4 pilihan jawaban menggunakan skala Likert rentang nilai 1 hingga 4. Skor ideal terendah bernilai 25 dan skor ideal tertinggi bernilai 100. 
Tabel 6. Kategori Data Angket Komponen Input Responden Siswa

\begin{tabular}{ccc}
\hline No. & Rentang Nilai & Kategori \\
\hline 1. & $X \geq 76$ & Sangat Sesuai \\
\hline 2. & $63 \leq X<76$ & Sesuai \\
\hline 3. & $50 \leq X<63$ & Tidak Sesuai \\
\hline 4. & $X<50$ & Sangat Tidak Sesuai \\
\hline \multicolumn{2}{c}{ Sumber: Djemari (2008) }
\end{tabular}

2. Evaluasi Process

a. Angket Penanggung Jawab TEFA, Guru Ahli Bidang Pengolahan, dan Supervisor Produksi Angket terdiri atas 42 pernyataan dengan 4 pilihan jawaban menggunakan skala Likert rentang nilai 1 hingga 4. Skor ideal terendah bernilai 42 dan skor ideal tertinggi bernilai 168.

Tabel 7. Kategori Data Angket Komponen Process Responden Guru

\begin{tabular}{ccc}
\hline No. & Rentang Nilai & Kategori \\
\hline 1. & $X \geq 126$ & Sangat Sesuai \\
\hline 2. & $105 \leq X<126$ & Sesuai \\
\hline 3. & $84 \leq X<105$ & Tidak Sesuai \\
\hline 4. & $X<84$ & Sangat Tidak Sesuai \\
\hline
\end{tabular}

b. Angket Siswa

Sumber: Djemari (2008)

Angket terdiri atas 17 pernyataan dengan 4 pilihan jawaban menggunakan skala Likert rentang nilai 1 hingga 4. Skor ideal terendah bernilai 17 dan skor ideal tertinggi bernilai 68 .

Tabel 8. Kategori Data Angket Komponen Process Responden Siswa

\begin{tabular}{ccc}
\hline No. & Rentang Nilai & Kategori \\
\hline 1. & $X \geq 52$ & Sangat Sesuai \\
\hline 2. & $43 \leq X<52$ & Sesuai \\
\hline 3. & $34 \leq X<43$ & Tidak Sesuai \\
\hline 4. & $X<34$ & Sangat Tidak Sesuai \\
\hline \multicolumn{2}{c}{ Sumber: Djemari (2008) }
\end{tabular}

3. Evaluasi Product

a. Angket Penanggung Jawab TEFA, Guru Ahli Bidang Pengolahan, dan Supervisor Produksi

Angket terdiri atas 12 pernyataan dengan 4 pilihan jawaban menggunakan skala Likert rentang 1 hingga 4. Skor ideal terendah bernilai 12 dan skor ideal tertinggi bernilai 48.

Tabel 9. Kategori Data Angket Komponen Product Responden Guru

\begin{tabular}{ccc}
\hline No. & Rentang Nilai & Kategori \\
\hline 1. & $X \geq 36$ & Sangat Sesuai \\
\hline 2. & $30 \leq X<36$ & Sesuai \\
\hline 3. & $24 \leq X<30$ & Tidak Sesuai \\
\hline 4. & $X<24$ & Sangat Tidak Sesuai \\
\hline \multicolumn{3}{c}{ Sumber: Djemari (2008) } \\
\hline
\end{tabular}

b. Angket Siswa

Angket terdiri atas 9 pernyataan dengan 4 pilihan jawaban menggunakan skala Likert rentang 1 hingga 4. Skor ideal terendah bernilai 9 dan skor ideal tertinggi bernilai 36 .

Tabel 10. Kategori Data Angket Komponen Product Responden Siswa

\begin{tabular}{ccc}
\hline No. & Rentang Nilai & Kategori \\
\hline 1. & $X \geq 28$ & Sangat Sesuai \\
\hline 2. & $23 \leq X<28$ & Sesuai \\
\hline 3. & $18 \leq X<23$ & Tidak Sesuai \\
\hline 4. & $X<18 \quad$ Sumber: Djemari (2008) & Sangat Tidak Sesuai \\
\hline \multicolumn{2}{c}{}
\end{tabular}

c. Angket Konsumen

Angket terdiri atas 7 pernyataan dengan 4 pilihan jawaban menggunakan skala Likert. Rentang nilai yang diberikan adalah 1 hingga 4 . Sehingga skor ideal terendah bernilai 7 dan skor ideal tertinggi bernilai 28.

Tabel 11. Kategori Data Angket Komponen Product Responden Konsumen

\begin{tabular}{ccc}
\hline No. & Rentang Nilai & Kategori \\
\hline 1. & $\mathrm{X} \geq 22$ & Sangat Sesuai \\
\hline 2. & $18 \leq \mathrm{X}<22$ & Sesuai \\
\hline 3. & $14 \leq \mathrm{X}<18$ & Tidak Sesuai \\
\hline 4. & $\mathrm{X}<14$ & Sangat Tidak Sesuai \\
\hline \multicolumn{2}{c}{ Sumber: Djemari (2008) }
\end{tabular}


Setelah diperoleh nilai pencapaian kelayakan dari total skor yang didapat dibagi dengan jumlah responden, selanjutnya persentase tersebut dibandingkan dengan nilai interval dari kriteria kesesuaian yang dapat dilihat pada Tabel 12.

Tabel 12. Kategori Kesesuaian

\begin{tabular}{cc}
\hline Persentase & Kategori \\
\hline $\mathbf{0} \%-\mathbf{2 4 , 9 9 \%}$ & Sangat Tidak Sesuai \\
\hline $\mathbf{2 5 \%}-\mathbf{4 9 , 9 9 \%}$ & Tidak Sesuai \\
\hline $\mathbf{5 0 \% - 7 4 , 9 9 \%}$ & Sesuai \\
\hline $\mathbf{7 5 \%}-\mathbf{1 0 0 \%}$ & Sangat Sesuai
\end{tabular}

Teknik analisis data kualitatif yang digunakan mencakup transkrip hasil wawancara dengan responden, reduksi data, penyajian data, analisis data, dan triangulasi. Teknik analisis data kualitatif tersebut disajikan dalam Gambar 1.

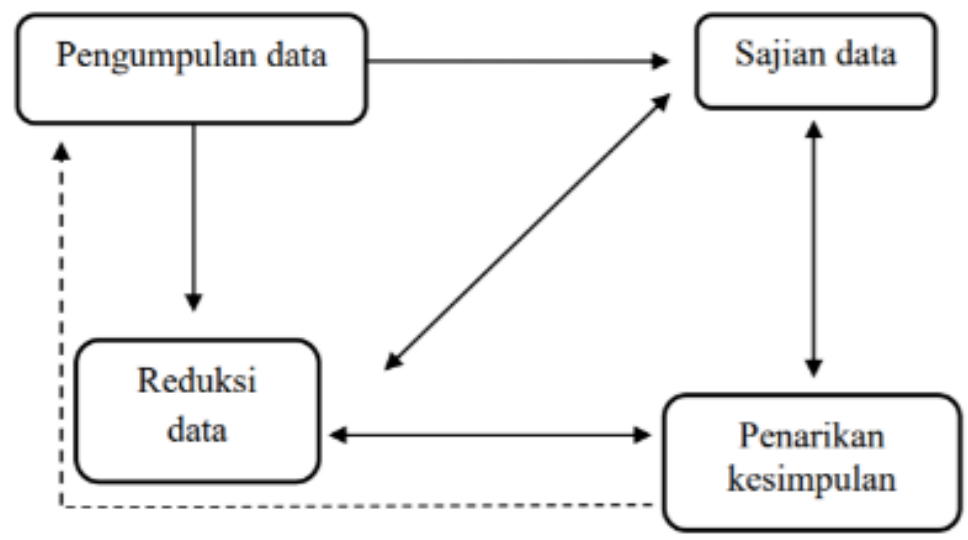

Gambar 1. Teknik Analisis Data Kualitatif (Sugiyono, 2007)

Setelah dilakukan analisis data, kegiatan terakhir adalah penarikan kesimpulan. Penarikan kesimpulan dan verifikasi merupakan tahap akhir dalam analisis data yang dilakukan untuk melihat hasil keseluruhan data yang dianalisis.

\section{HASIL DAN PEMBAHASAN}

Pemaparan temuan hasil penelitian diperoleh dari instrumen angket, wawancara, observasi, dan dokumentasi di SMKN 1 Cibadak.

\section{Komponen Context}

Komponen context berhubungan dengan tujuan, visi dan misi, standar pelaksanaan atau kebijakan pemerintah, kontribusi pihak sekolah dan pihak luar model pembelajaran TEFA SMKN 1 Cibadak. Berdasarkan Fuadi (2016), analisis dalam komponen context menyangkut landasan format TEFA dan kebijakan kepala sekolah. Matriks analisis hasil wawancara dengan responden kepala sekolah untuk komponen context dapat dilihat pada Tabel 13.

Tabel 13. Tabel Hasil Evaluasi Komponen Context

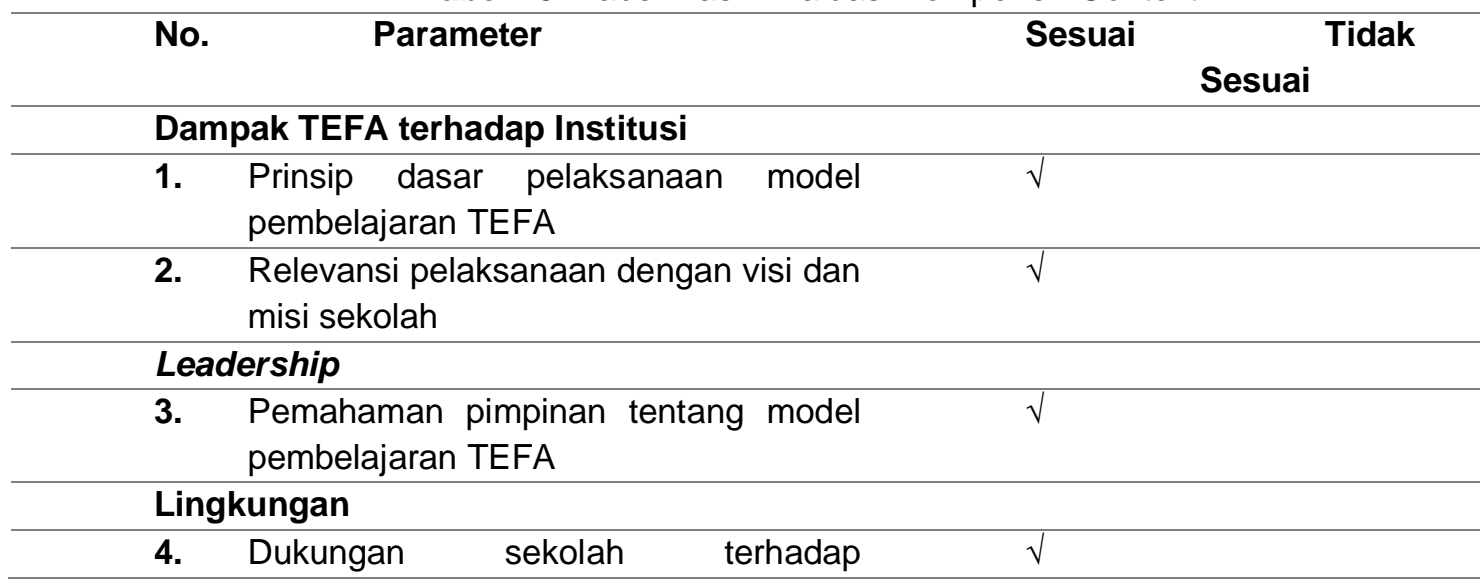




\begin{tabular}{|c|c|c|c|}
\hline \multirow[t]{2}{*}{ No. } & Parameter & Sesuai & Tidak \\
\hline & & \multicolumn{2}{|r|}{ Sesuai } \\
\hline \multicolumn{4}{|c|}{ pengembangan program } \\
\hline 5. & $\begin{array}{l}\text { Dukungan sekolah terhadap sarana dan } \\
\text { prasarana }\end{array}$ & & $\sqrt{ }$ \\
\hline \multicolumn{4}{|c|}{ Bentuk Kerja Sama } \\
\hline 6. & $\begin{array}{l}\text { Dukungan industri terhadap kompetensi } \\
\text { kerja siswa }\end{array}$ & $\sqrt{ }$ & \\
\hline 7. & $\begin{array}{l}\text { Dukungan industri terhadap legalitas } \\
\text { produk }\end{array}$ & $\sqrt{ }$ & \\
\hline 8. & $\begin{array}{l}\text { Dukungan industri terhadap transfer } \\
\text { teknologi }\end{array}$ & $\sqrt{ }$ & \\
\hline \multicolumn{2}{|c|}{ Total } & 7 & 1 \\
\hline \multicolumn{2}{|c|}{ Persentase Tingkat Kesesuaian } & $87,5 \%$ & \\
\hline
\end{tabular}

Berdasarkan keseluruhan evaluasi terhadap komponen context dengan sub-komponen manajemen sekolah pada Tabel 13., dapat dilihat dari empat parameter yang diukur bahwa ketiganya telah dilaksanakan sesuai dengan ketentuan. Hasil ini menunjukkan bahwa pihak sekolah sebagai penanggung jawab pusat telah memberikan dukungan, meningkatkan, dan mengembangkan dukungan terhadap keberlangsungan model pembelajaran TEFA di sekolah. Berdasarkan Peraturan Menteri Pendidikan dan Kebudayaan RI Nomor 60 Tahun 2014 mengenai pengembangan kurikulum peminatan kejuruan bahwa kurikulum di SMKN 1 Cibadak telah disesuaikan agar terlaksananya integrasi pengalaman dunia kerja dalam bentuk pembelajaran produktif. Selain itu dilaksanakan sertifikasi kompetensi keahlian yang dikembangkan oleh komite BNSP dan Direktorat Pembinaan SMK agar mendapatkan sertifikasi kelayakan melalui ujian kompetensi.

Pada parameter lingkungan berupa sub-parameter dukungan sekolah terhadap sarana dan prasarana, sarana dan prasarana di unit produksi perlu ditingkatkan secara berkelanjutan agar kegiatan pembelajaran siswa dapat berjalan dengan lancar sesuai dengan tujuan institusi. Dukungan sekolah berperan penting dalam keberlangsungan program. Hal ini sejalan dengan penelitian Indahsari (2017), evaluasi terkait sub-parameter lingkungan berupa dukungan teknologi berupa fasilitas dengan teknologi terkini dan dukungan kurikulum sebagai acuan pelaksanaan pembelajaran. Berdasarkan observasi, fasilitas di tempat praktik di TEFA serealia belum dilaksanakan secara maksimum dan memerlukan perbaikan.

Sementara sub-komponen hubungan industri dari tiga sub-parameter yang diukur bahwa ketiganya telah dilaksanakan sesuai dengan ketentuan. Hasil ini menunjukkan bahwa pihak industri sebagai mitra sekolah memberikan dukungan dan berperan besar dalam pengembangan model pembelajaran TEFA pada institusi vokasi. Sejalan dengan penelitian Yunanto (2016) bahwa hubungan industri berperan penting dalam pelaksanaan TEFA di sekolah kejuruan karena berpengaruh terhadap pengetahuan teknis, skill grup, dan pengalaman kerja dunia nyata siswa. Dukungan pihak industri telah dilakukan semenjak tahun 2014 seperti transfer teknologi, kegiatan prakerin siswa, magang guru, dan guru tamu. Selain itu, pihak industri membantu institusi vokasi untuk memiliki izin legalitas edar produk dengan standar minimal P-IRT.

\section{Komponen Input}

Berdasarkan Fuadi (2016), komponen input mencakup analisis yang berhubungan dengan penggunaan sumber daya yang tersedia dan alternatif strategi yang dikembangkan dalam pencapaian program. Komponen input berhubungan dengan sarana-prasarana atas manajemen, bengkel-lab terdiri dari peralatan, tata kelola penggunaan alat, ruang praktik, manajemen maintenance, repair \& calibration (MRC) serta layout ruang praktik lalu sumber daya manusia terdiri dari kompetensi TEFA, kesesuaian SDM guru, motivasi, inovasi, dan teamwork. 


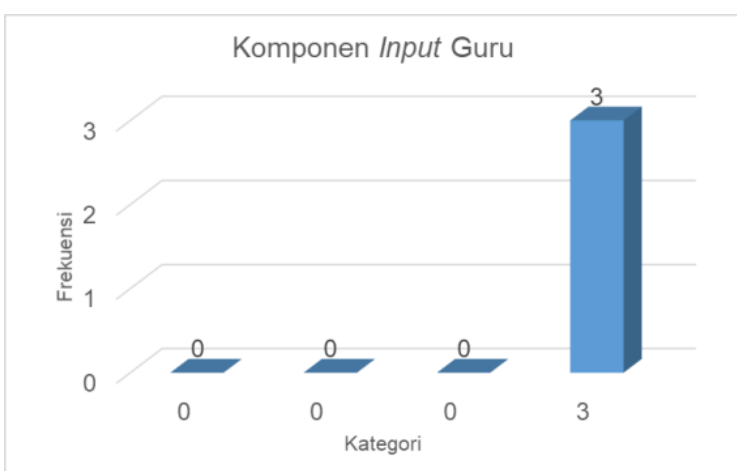

Gambar 2. Distribusi Frekuensi Data Komponen Input Responden Guru

Angket terdiri atas 38 butir pernyataan. Berdasarkan Gambar 2. tidak ada responden dalam kategori tidak sesuai $(0 \%)$, kurang sesuai $(0 \%)$, dan sesuai $(0 \%)$. NPK dari komponen input responden guru dapat dilihat pada Tabel 14.

Tabel 14. Nilai Pencapaian Kualitas Kesesuaian Pelaksanaan Model Pembelajaran TEFA

Komponen Input Responden Guru

\begin{tabular}{llllll}
\hline $\begin{array}{l}\text { Jumlah } \\
\text { Responden }\end{array}$ & $\begin{array}{l}\text { Jumlah } \\
\text { Soal }\end{array}$ & Total Skor & NPK & $\begin{array}{l}\text { Persentase } \\
(\%)\end{array}$ & Keterangan \\
\hline $\mathbf{3}$ & 38 & 384 & 128 & 84,21 & Sangat Sesuai \\
\hline
\end{tabular}

Berdasarkan Tabel 14., kesesuaian pelaksanaan model pembelajaran TEFA komponen input responden guru termasuk kedalam kategori sangat sesuai yang ditunjukkan oleh nilai NPK 128 dengan persentase $84,21 \%$. Sekolah merupakan suatu sistem terdiri atas tujuan yang menjadi arah dan mengarahkan sistem, lalu terdapat arus jaringan kerja dan sejumlah posisi yang saling berkaitan dalam mencapai tujuan (Norlena, 2015). Manajemen sekolah merupakan salah satu unsur penting sebagai penggerak kinerja institusi (Supriyantoko dkk, 2020). Pada pelaksanaan pelayanan administrasi, telah terdapat laporan pencatatan berupa perubahan modal, buku stok bahan-bahan baku, bon pemakaian alat praktik, buku kas pendapatan, dan buku kas pengeluaran yang digunakan untuk kegiatan praktik model pembelajaran TEFA. Hal tersebut sesuai dengan penelitian Indahsari (2017) bahwa model pembelajaran TEFA sebagai bentuk miniatur industri di sekolah dapat disamakan dengan perusahaan manufaktur, sehingga perlu terdapat kenetuan minimal dalam bentuk administrasi keuangan yang berhubungan dengan pencatatan transaksi. Sarana produksi telah tersedia baik jumlah maupun jenis proporsional dengan jumlah siswa. Alat besar memerlukan kegiatan MRC dalam jangka waktu tertentu agar bertujuan untuk menjaga reabilitas dan keamanan.

Dalam mengarahkan pelayanan yang diberikan serta hasil yang dicapai untuk memenuhi kebutuhan konsumen dibutuhkan suatu standar yang digunakan. Penyusunan standar pelayanan dapat diketahui apabila terdapat rangkaian prosedur yang distandarkan atau yang lebih dikenal sebagai standar operasional prosedur (SOP) (Nafiah, 2011). Menurut Dwilestari (2019) bahwa dokumen SOP sebagai parameter manajemen yang perlu dimiliki agar meningkatkan kompetensi lulusan dan memenuhi kebutuhan dunia industri dan dunia usaha. Formulir pemakaian dan peminjaman alat praktik telah tersedia dan digunakan. Layout ruangan praktik cukup sesuai karena siswa bekerja dalam alur kerja proses produksi sesuai dengan SOP yang tersedia. Namun belum tersedia ruangan terpisah antara proses produksi dengan ruang penyimpanan bahan ataupun ruang pengemasan. Kondisi penyimpanan bahan baku dan peralatan perlu diperbaiki agar terorganisir dan tertata dengan baik. Hal tersebut didukung oleh penelitian Fuadi (2016), bahwa bangunan gedung untuk TEFA pengolahan perlu dan terdapat beberapa ruang dengan fungsi yang berbeda antara lain, seperti ruang produksi, ruang administrasi, dan ruang briefing serta toilet terpisah. 


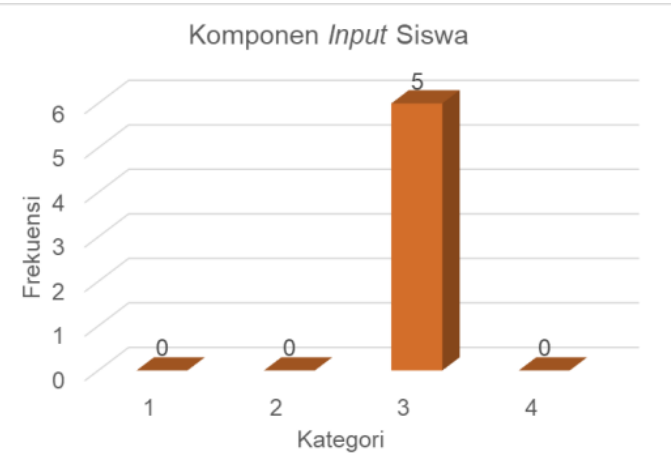

Gambar 3. Distribusi Frekuensi Data Komponen Input Responden Siswa

Angket terdiri atas 23 butir pernyataan. Berdasarkan Gambar 3. tidak ada responden dalam kategori tidak sesuai $(0 \%)$, kurang sesuai $(0 \%)$, dan sangat sesuai $(0 \%)$. NPK dari komponen input responden siswa dapat dilihat pada Tabel 15.

Tabel 15. Nilai Pencapaian Kualitas Kesesuaian Pelaksanaan Model Pembelajaran TEFA Komponen Input Responden Siswa

\begin{tabular}{llllll}
\hline $\begin{array}{l}\text { Jumlah } \\
\text { Responden }\end{array}$ & $\begin{array}{l}\text { Jumlah } \\
\text { Soal }\end{array}$ & Total Skor & NPK & $\begin{array}{l}\text { Persentase } \\
(\%)\end{array}$ & Keterangan \\
\hline $\mathbf{5}$ & 23 & 319 & 63,8 & 69,35 & Sesuai \\
\hline
\end{tabular}

Berdasarkan Tabel 15., kesesuaian pelaksanaan model pembelajaran TEFA komponen input responden siswa termasuk kedalam kategori sesuai yang ditunjukkan oleh nilai NPK 63,8 dengan persentase $69,35 \%$. Berdasarkan wawancara responden, guru memandu siswa memahami diagram alir produksi, penentuan bahan baku, penentuan peralatan, penerapan $\mathrm{K} 3$, pengarahan pembuatan produk selama proses produksi, dan menentukan harga produk. Kegiatan MRC belum pernah dilaksanakan untuk alat-alat besar. Bahkan kegiatan maintenance pengecekan rutin hanya dilakukan sebelum kegiatan praktik oleh teknisi sekolah. Berdasarkan penelitian Indahsari (2017) bahwa dengan RPP yang mengimplementasikan konsep TEFA harus mencapai minimal level 5, level 6, dan level 7 . Pada level tersebut mempertimbangkan aspek MRC pada peralatan kegiatan produksi serta terdapat penanggung jawab khusus dalam bidang MRC. Perawatan merupakan kegiatan memelihara dan menjaga fasilitas agar dapat digunakan sesuai dengan apa yang direncanakan (Manesi, 2015). Sejauh ini perawatan fasilitas praktik masih dilakukan secara manual, apabila terjadi kerusakan baru dilakukan langkah perbaikan dan hanya dibebankan kepada teknisi.

\section{Komponen Process}

Komponen process berhubungan dengan implementasi model pembelajaran, seperti pola pembelajaran, training, marketing, dan promosi produk TEFA.

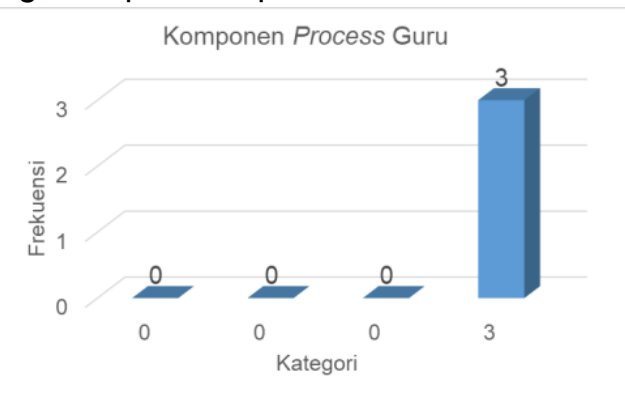

Gambar 4. Distribusi Frekuensi Data Komponen Process Responden Guru

Angket terdiri atas 38 butir pernyataan. Berdasarkan Gambar 4. tidak ada responden dalam kategori tidak sesuai $(0 \%)$, kurang sesuai $(0 \%)$, dan sesuai $(0 \%)$. NPK dari komponen process responden guru dapat dilihat pada Tabel 16, dimana kesesuaian pelaksanaan model pembelajaran TEFA komponen process responden guru termasuk kedalam kategori sangat sesuai yang ditunjukkan oleh nilai NPK 139,33 dengan persentase 91,67\%. Pembelajaran di sekolah kejuruan diharapkan memenuhi ketiga komponen pengetahuan, keterampilan, dan sikap. 
Tabel 16. Nilai Pencapaian Kualitas Kesesuaian Pelaksanaan Model Pembelajaran TEFA Komponen Process Responden Guru

\begin{tabular}{llllll}
\hline $\begin{array}{l}\text { Jumlah } \\
\text { Responden }\end{array}$ & $\begin{array}{l}\text { Jumlah } \\
\text { Soal }\end{array}$ & Total Skor & NPK & $\begin{array}{l}\text { Persentase } \\
(\%)\end{array}$ & Keterangan \\
\hline $\mathbf{3}$ & 38 & 418 & 139,33 & 91,67 & Sangat Sesuai \\
\hline
\end{tabular}

Dalam penjabarannya yaitu pembelajaran normatif untuk membangun karakter dan kepribadian, pembelajaran adaptif untuk pengembangan kemampuan yang berkelanjutan, serta pembelajaran produktif untuk kemampuan pada keahlian sebagai bekal memasuki dunia kerja (Baiti, 2014). Agar dapat melaksanakan pembelajaran terarah dan tujuan pembelajaran dicapai dengan baik, perlu ada perencanaan pembelajaran. Rencana pelaksanaan pembelajaran (RPP) dan modul praktikum telah tersedia digunakan untuk kegiatan praktik siswa. Guru menyiapkan perencanaan pembelajaran dengan dokumen-dokumen penunjang, seperti RPP, worksheet dalam bentuk modul praktikum, jadwal kegiatan, agenda, daftar nilai, absensi, dan kriteria ketuntasan minimal siswa. Penyusunan RPP perlu untuk disesuaikan dengan kebutuhan implementasi model pembelajaran TEFA, sehingga terdapat acuan dan cara untuk mencapai tujuan pembelajaran dalam kegiatan pembelajaran (Indahsari, 2017). Dengan diterapkannya model pembelajaran TEFA, siswa mampu melaksanakan kegiatan praktikum dalam suasana dan etos kerja seperti tuntutan industri. Sebelum memasuki ruangan, siswa dibariskan terpisah diluar ruangan untuk absensi antara siswa yang tepat waktu maupun tidak. Pengecekan kelengkapan APD dan penggunaan APD, pelaksanaan kegiatan K3 dasar seperti sanitasi ruang praktik.

Lulusan SMK selain sebagai lulusan yang memiliki kemampuan mencari pekerjaan, menjadi lebih luas cakupannya dengan kemampuan bagaimana menciptakan lapangan pekerjaan dalam menjadi wirausaha (Sabatari dkk, 2013). Pengembangan jiwa kewirausahaan dapat dikembangkan melalui pembelajaran TEFA karena siswa dilibatkan dari persiapan produksi hingga penerimaan barang kepada konsumen. Selain siswa memiliki kemampuan pengolahan pangan, siswa pun memiliki rasa tanggung jawab, komitmen, etos kerja, berpikir kreatif, dan berperilaku inovatif. Hal ini diperkuat dengan penelitian Indahsari (2017) bahwa hasil pembelajaran TEFA tidak hanya membentuk karakter siswa yang siap bekerja di dunia industri, tetapi juga siap kerja secara mandiri. Indikator mengenai rencana pemasaran utamanya masih melalui direct sales. Sekolah belum memiliki kegiatan pemasaran dengan target pasar yang direncanakan dengan jelas. Dengan tidak adanya kegiatan marketing dan promosi yang jelas menyebabkan produk TEFA tidak mengalami perkembangan jangkauan pasar (Indahsari, 2017). Media sosial yang digunakan untuk mempromosikan produk adalah akun whatsapp, akun facebook, akun instagram, dan website sekolah. Bersamaan dengan kegiatan marketing dan promosi, kegiatan layanan konsumen melalui contact person khusus tidak dilakukan karena masukkannya tidak tersedia. Hal ini didukung oleh penelitian Indahsari (2017), bahwa kegiatan layanan konsumen perlu dilaksanakan dengan baik karena konsumen merupakan penentu berjalannya suatu usaha, termasuk untuk model pembelajaran TEFA agar memudahkan konsumen untuk pemesanan produk.

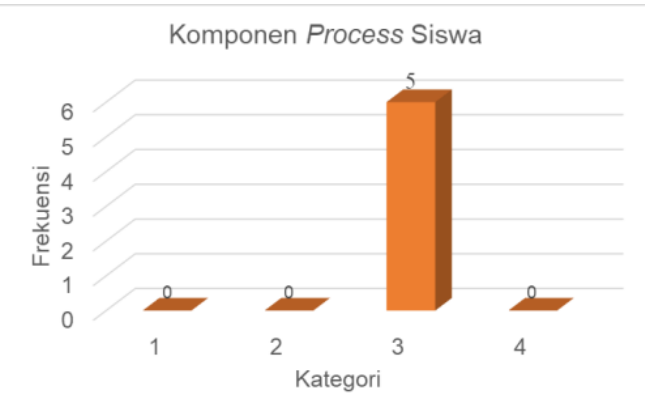

Gambar 5. Distribusi Frekuensi Data Komponen Process Responden Siswa

Angket terdiri atas 16 butir pernyataan. Berdasarkan Gambar 5. tidak ada responden dalam kategori tidak sesuai $(0 \%)$, kurang sesuai $(0 \%)$, dan sangat sesuai $(0 \%)$. NPK dari komponen process responden siswa dapat dilihat pada Tabel 17. 
Tabel 17. Nilai Pencapaian Kualitas Kesesuaian Pelaksanaan Model Pembelajaran TEFA Komponen Process Responden Siswa

\begin{tabular}{llllll}
\hline $\begin{array}{l}\text { Jumlah } \\
\text { Responden }\end{array}$ & $\begin{array}{l}\text { Jumlah } \\
\text { Soal }\end{array}$ & Total Skor & NPK & $\begin{array}{l}\text { Persentase } \\
(\%)\end{array}$ & Keterangan \\
\hline $\mathbf{5}$ & 16 & 242 & 48,4 & 71,18 & Sesuai \\
\hline
\end{tabular}

Berdasarkan Tabel 17., kesesuaian pelaksanaan model pembelajaran TEFA komponen process responden siswa termasuk kedalam kategori sesuai yang ditunjukkan oleh nilai NPK 48,4 dengan persentase $71,18 \%$. Dengan adanya model pembelajaran TEFA, siswa tidak hanya mempelajari bagaimana memproduksi barang tetapi juga mempromosikan barang tersebut langsung kepada konsumen. Siswa bertugas untuk mencari konsumen yang akan memesan produk yang dibuat oleh mereka sendiri. Penerapan etika kerja dilakukan dari sebelum kegiatan pembelajaran dilakukan, seperti kegiatan K3, penggunaan APD dengan benar, serta pengisian formulir alat dan bahan. Hal tersebut sejalan dengan penelitian Fuadi (2016) mengenai aspek kesiapan siswa dalam pelaksanaan model pembelajaran TEFA yang menggunakan dua indikator, yakni siswa dibekali materi kewirausahaan dan siswa dibekali pengetahuan awal dalam proses produksi.

Institusi perlu untuk mengevaluasi implementasi model pembelajaran TEFA dalam kejelasan target, segmen pasar, dan jangkauan pasar serta menyesuaikan metode dan pelaku kegiatan promosi (Direktorat PSMK, 2016). Kegiatan marketing atau rencana pemasaran produk TEFA perlu mencakup kejelasan target, segmen pasar, jangkauan pasar, serta metode dan pelaku kegiatan promosi. Berdasarkan hasil angket dan wawancara dengan responden, kegiatan pemasaran masih kurang dilaksanakan karena produk TEFA masih membutuhkan peningkatan dalam hal pemasaran kepada masyarakat secara umum. Rencana pemasaran masih dilakukan secara lisan sehingga tingkat pelaksanaannya belum diketahui secara pasti.

\section{Komponen Product}

Evaluasi terhadap komponen product dilakukan untuk melihat hasil yang dicapai, selama pelaksanaan maupun pada akhir pelaksanaan program (Fuadi, 2016). Komponen product berhubungan dengan produk/jasa yang mencakup produk untuk kebutuhan internal, keberterimaan terhadap pasar, delivery, quality, dan quality control serta kompetensi yang didapat siswa melalui model pembelajaran TEFA.

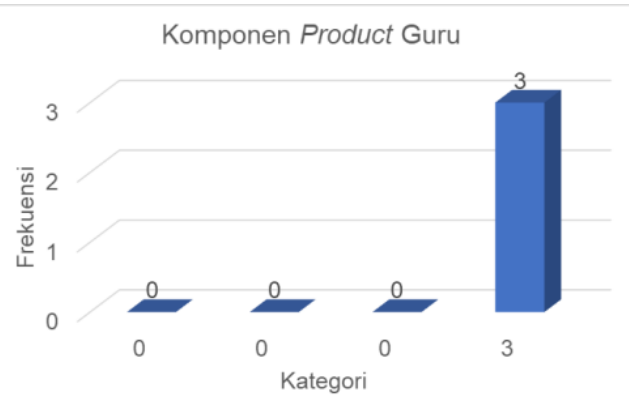

Gambar 6. Distribusi Frekuensi Data Komponen Product Responden Guru

Angket terdiri atas 12 butir pernyataan. Berdasarkan Gambar 6. tidak ada responden dalam kategori tidak sesuai $(0 \%)$, kurang sesuai $(0 \%)$, dan sesuai $(0 \%)$. NPK dari komponen product responden guru dapat dilihat pada Tabel 18.

Tabel 18. Nilai Pencapaian Kualitas Kesesuaian Pelaksanaan Model Pembelajaran TEFA Komponen Product Responden Guru

\begin{tabular}{llllll}
\hline $\begin{array}{l}\text { Jumlah } \\
\text { Responden }\end{array}$ & $\begin{array}{l}\text { Jumlah } \\
\text { Soal }\end{array}$ & Total Skor & NPK & $\begin{array}{l}\text { Persentase } \\
(\%)\end{array}$ & Keterangan \\
\hline $\mathbf{3}$ & 12 & 135 & 45 & 93,75 & Sangat Sesuai \\
\hline
\end{tabular}

Berdasarkan Tabel 18., kesesuaian pelaksanaan model pembelajaran TEFA komponen product responden guru termasuk kedalam kategori sangat sesuai yang ditunjukkan oleh nilai NPK 45 dengan persentase $93,75 \%$. Dalam menghasilkan produk, kualitas merupakan faktor yang membawa 
keberhasilan, pertumbuhan, dan peningkatan posisi bersaing antara produk satu dengan lainnya untuk mampu memuaskan keinginan konsumen (Ginting, 2017). Produk hasil berupa bakpia ubi ungu memiliki standar SNI 01-4291-1996 mengenai kenampakan, bau, rasa, warna, dan tekstur. Berdasarkan wawancara dengan responden, warna yang dihasilkan menarik dan sesuai dengan standar berwarna putih keemasan. Aroma produk dinilai enak, cukup kuat, dan bertahan lama. Tekstur yang dihasilkan renyah dibagian kulit luar ketika masih hangat dan apabila telah dingin menjadi lembut. Namun hal yang menjadi perhatian adalah ketebalan lapisan kulit, ada yang tebal dan tipis sehingga tidak seragam. Penjaminan kualitas dilakukan secara organoleptik, yakni ppengamatan secara kenampakan luar saja. Supervisor produksi dan siswa mengecek apakah terdapat produk yang tidak layak jual, seperti gosong. Kegiatan pengawasan mutu perlu dilakukan untuk menjaga kualitas dan keamanan pangan produk saat dipasarkan (Indahsari, 2017).

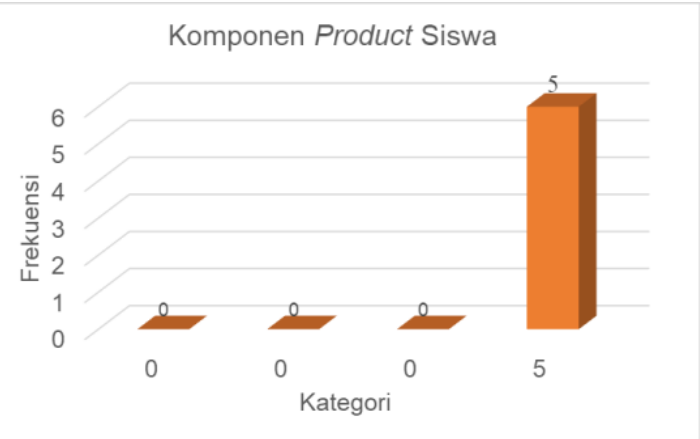

Gambar 7. Distribusi Frekuensi Data Komponen Product Responden Siswa

Angket terdiri atas 9 butir pernyataan. Berdasarkan Gambar 7. tidak ada responden dalam kategori tidak sesuai $(0 \%)$, kurang sesuai $(0 \%)$, dan sesuai $(0 \%)$. NPK dari komponen product responden siswa dapat dilihat pada Tabel 19.

Tabel 10. Nilai Pencapaian Kualitas Kesesuaian Pelaksanaan Model Pembelajaran TEFA Komponen Product Responden Siswa

\begin{tabular}{llllll}
\hline $\begin{array}{l}\text { Jumlah } \\
\text { Responden }\end{array}$ & $\begin{array}{l}\text { Jumlah } \\
\text { Soal }\end{array}$ & Total Skor & NPK & $\begin{array}{l}\text { Persentase } \\
(\%)\end{array}$ & Keterangan \\
\hline $\mathbf{5}$ & 9 & 145 & 29 & 80,56 & Sangat Sesuai \\
\hline
\end{tabular}

Berdasarkan Tabel 19., kesesuaian pelaksanaan model pembelajaran TEFA komponen product responden guru termasuk kedalam kategori sangat sesuai yang ditunjukkan oleh nilai NPK 29 dengan persentase $80,56 \%$. Keberhasilan program sekolah kejuruan secara tuntas berorientasi kepada penampilan para lulusan di lapangan kerja (Direktorat PSMK, 2016). Kompetensi yang dibutuhkan pihak industri dapat dibagi menjadi 2, yaitu soft competency dan hard competency. Berdasarkan wawancara dengan responden, dengan adanya model pembelajaran TEFA, siswa dapat melakukan proses produksi mulai dari persiapan hingga pengantaran produk kepada konsumen. Sehingga mampu mengetahui letak berhasil atau tidaknya suatu proses, sikap tanggung jawab, ketelitian, kemandirian, dan mengembangkan jiwa kewirausahaan. Siswa sudah mampu mencapai nilai minimal kelulusan dalam mata pelajaran produktif yang menerapkan model pembelajaran TEFA. Hal ini sejalan dengan penelitian (Indahsari, 2017) bahwa kemampuan kognitif siswa meningkat dan siswa mampu mencapai kriteria ketentuan minimal setelah diterapkannya model pembelajaran TEFA.

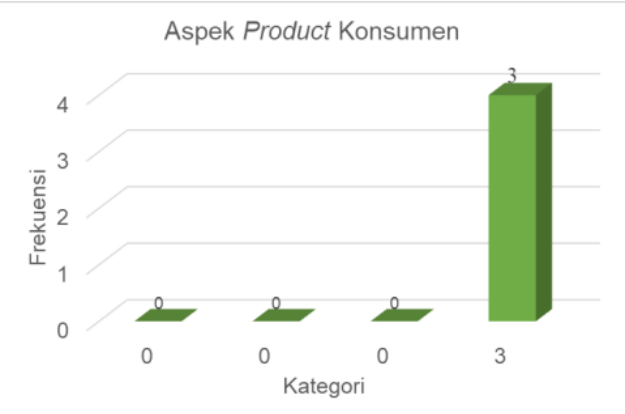

Gambar 7. Distribusi Frekuensi Data Komponen Product Responden Konsumen 
Angket terdiri atas 7 butir pernyataan. Berdasarkan Gambar 7. tidak ada responden dalam kategori tidak sesuai $(0 \%)$, kurang sesuai $(0 \%)$, dan sesuai $(0 \%)$. NPK dari komponen product responden konsumen dapat dilihat pada Tabel 20.

Tabel 20. Nilai Pencapaian Kualitas Kesesuaian Pelaksanaan Model Pembelajaran TEFA Komponen Product Responden Konsumen

\begin{tabular}{llllll}
\hline $\begin{array}{l}\text { Jumlah } \\
\text { Responden }\end{array}$ & $\begin{array}{l}\text { Jumlah } \\
\text { Soal }\end{array}$ & Total Skor & NPK & $\begin{array}{l}\text { Persentase } \\
(\%)\end{array}$ & Keterangan \\
\hline $\mathbf{3}$ & 7 & 77 & 25,67 & 91,67 & Sangat Sesuai \\
\hline
\end{tabular}

Berdasarkan Tabel 20., kesesuaian pelaksanaan model pembelajaran TEFA komponen product responden konsumen termasuk kedalam kategori sangat sesuai yang ditunjukkan oleh nilai NPK 25,67 dengan persentase 91,67\%. Konsep pembelajaran berbasis industri bahwa produk praktik yang dihasilkan merupakan sesuatu yang berguna dan bernilai ekonomi dan diterima oleh pasar (Direktorat PSMK, 2016). Berdasarkan wawancara dengan responden, secara keseluruhan produk bakpia ubi ungu menarik dan memiliki kualitas produk yang tidak kalah bersaing dengan produk di pasaran. Hal tersebut didukung oleh penelitian Fuadi (2016), bahwa hasil produksi TEFA siswa telah layak jual dengan dibuktikan diterimanya produk oleh pasar. Rasa yang dihasilkan tidak terlalu manis dan sesuai dengan keinginan konsumen. Filling yang menjadi rasa ciri khas pun terasa asli tanpa ada bahan tambahan pangan artifisial. Pada segi tekstur konsumen merasa belum menyerupai dengan bakpia asal Yogyakarta namun masih dapat diterima. Pada segi variasi pun diharapkan ada varian lain selain rasa ubi ungu. Selain penilaian terhadap produk, untuk segi kemasan sudah bagus dan menarik. Konsumen menginginkan ketahanan produk lebih lama karena produk baru bisa bertahan selama 5-7 hari pada suhu ruang.

\section{KESIMPULAN}

1. Pelaksanaan TEFA ditinjau dari komponen context termasuk dalam kategori sangat sesuai terhadap relevansi pelaksanaan TEFA dengan tujuan program, visi dan misi sekolah. Pada dukungan pihak industri terhadap model pembelajaran TEFA telah dilaksanakan dengan baik, tetapi membutuhkan peningkatan dalam pengembangan teknologi dan kurikulum sehingga berdampak terhadap lulusan kompeten yang sesuai dengan persyaratan industri.

2. Pelaksanaan TEFA ditinjau dari komponen input termasuk dalam kategori sesuai terhadap manajemen sekolah, sarana, prasarana, dan sumber daya manusia. Pelaksanaan manajemen sekolah dan kegiatan MRC peralatan praktik telah terlaksana, tetapi membutuhkan peningkatan dalam manajemen pengelolaan sumber daya sehingga dapat terpakai secara efektif dan efisien sesuai dengan rencana.

3. Pelaksanaan TEFA ditinjau dari komponen process dinyatakan sangat sesuai terhadap pola pembelajaran dan marketing. Pelaksanaan rencana pemasaran, media komunikasi, dan penggunaan media pemasaran telah dilaksanakan dengan baik tetapi membutuhkan peningkatan sehingga mampu memfasilitasi permintaan pasar yang bernilai jual bagi konsumen, klien, dan masyarakat.

4. Pelaksanaan TEFA ditinjau dari komponen product dinyatakan sangat sesuai terhadap produk yang dihasilkan dan kompetensi yang didapat oleh siswa. Hal ini menunjukkan bahwa penerapan model pembelajaran TEFA mampu menumbuhkan keterampilan siswa yang dibutuhkan di dunia industri, mengembangkan jiwa kewirausahaan, dan meningkatkan hasil aktivitas belajar dengan pencapaian nilai minimal kelulusan dalam mata pelajaran produktif.

\section{DAFTAR PUSTAKA}

Baiti, A. (2014). Pengaruh Pengalaman Praktik, Prestasi Belajar Dasar Kejuruan dan Dukungan Orang Tua Terhadap Kesiapan Kerja Siswa SMK. Jurnal Pendidikan Vokasi, 4(2), hal. 164-180.

Direktorat Pembinaan SMK. (2017). Tatakelola Pelaksanaan Teaching Factory. Jakarta: Kementerian Pendidikan dan Kebudayaan Republik Indonesia.

Direktorat Pembinaan SMK. (2019). Panduan Pengembangan Teaching Factory. Jakarta: Kementerian Pendidikan dan Kebudayaan Republik Indonesia.

Djemari, M. (2008). Teknik Penyusunan Instrumen Tes dan Non-tes. Yogyakarta: Mitra Cendekia 
Press.

Dwilestari, N. (2019). Pengembangan Standard Operating Procedure (SOP) Teaching Factory Produk Kopi Arabika Berbasis SKKNI di SMK PP Negeri Lembang. S1 thesis, Universitas Pendidikan Indonesia.

Fuadi, A. (2016). Evaluasi Program Pembelajaran Teaching Factory di Sekolah Usaha Perikanan Menengah. Balai Diklat Aparatur Sukamandi, Kementerian Kelautan dan Perikanan. 30(2), hal. 113-124.

Ginting, E. B. (2017). Hubungan Tindakan Pengrajin Selama Proses Pengolahan dengan Karakteristik Mutu dan Tingkat Kesukaan Bakpia di Daerah Pathuk Yogyakarta. Doctoral dissertation, Universitas Mercu Buana Yogyakarta.

Indahsari, E. (2017). Evaluasi Pelaksanaan Model Pembelajaran Teaching Factory pada Pembelajaran Produktif TPHP. S1 thesis, Universitas Pendidikan Indonesia.

Jenkins, A., \& Pepper, D. (1976). Proceedings of the 1975 National Conference on Geography in Higher Education. Oxford: Publications Office, Oxford Polytechnic.

Kholifah, H. (2019). Pengembangan Modul Praktikum pada Kompetensi Dasar Pengoperasian Peralatan Pengolahan di SMK Pertanian Pembangunan Negeri Lembang. S1 thesis, Universitas Pendidikan Indonesia.

Nafiah, D. (2011). Peranan Standar Operasional Prosedur (SOP) dalam Menunjang Pengelolaan Administrasi Sekolah. Efisiensi : Kajian Ilmu Administrasi, 11(1), hal. 38-49.

Norlena, I. (2015). Sekolah Sebagai Organisasi Formal (Hubungan Antar Struktur). Tarbiyah Islamiyah, 5(2), hal. 43-55.

Manesi, D. (2015). Penerapan Preventive Maintenance untuk Meningkatkan Kinerja Fasilitas Praktik Laboratorium Prodi Pendidikan Teknik Mesin UNDANA. Jurnal Teknologi, FST Undana, 4(3), hal. 09-17.

Martawijaya, D. H. (2015). Teaching Factory 6 Langkah (Model TF-6M). [Online]. Diakses dari http://www.tf6m.com/model-tf-6m/.

Sabatari, W., \& Hariyanto, V. (2013). Upaya Pembelajaran Kewirausahaan di SMK Potret Komitmen Terhadap Standar Nasional Proses Pendidikan dan Pembelajaran. Jurnal Pendidikan Teknologi dan Kejuruan, 21(3), hal. 285-293.

Sugiyono. (2007). Metode Penelitian Pendidikan. Bandung: Alfabeta.

Suharsimi, A., \& Jabar, C. (2004). Evaluasi Program Pendidikan : Pedoman Teoritis Praktis bagi Praktisi Pendidikan. Jakarta: Bumi Aksara.

Supriyantoko, I., dkk. (2020). Evaluasi Implementasi Kebijakan Teaching Factory dengan Model Evaluasi CIPP Di SMK Negeri DKI Jakarta. Journal of Vocational and Technical Education (JVTE), 2(2), hal. 01-10.

Stufflebeam, D.L., McKee, H., dan McKee, B. (2003). The CIPP Model for Evaluation. Paper presented at the 2003 Annual Conference of the Oregon Program Evaluation Network (OPEN). Portland, Oregon.

Yunanto, D. (2016). Implementasi Teaching Factory Di SMKN 2 Gedangsari Gunungkidul. Vidya Karya, 31(1), hal. 29-36. 